\title{
Effects of fat content, pasteurization method, homogenization pressure, and storage time on the mechanical and sensory properties of bovine milk
}

\author{
Y. Li, ${ }^{*}$ H. S. Joyner, $\dagger^{1}$ B. G. Carter, $\ddagger$ and M. A. Drake $\ddagger$ \\ *School of Food Science, Washington State University, Pullman 99163 \\ †School of Food Science, University of Idaho, Moscow 83843 \\ †Department of Food, Bioprocessing, and Nutrition Sciences, Southeast Dairy Foods Research Center, North Carolina State University, \\ Raleigh 27695
}

\section{ABSTRACT}

Fluid milk may be pasteurized by high-temperature short-time pasteurization (HTST) or ultrapasteurization (UP). Literature suggests that UP increases milk astringency, but definitive studies have not demonstrated this effect. Thus, the objective of this study was to determine the effects of pasteurization method, fat content, homogenization pressure, and storage time on milk sensory and mechanical behaviors. Raw skim ( $<0.2 \%$ fat), $2 \%$, and $5 \%$ fat milk was pasteurized in duplicate by indirect UP $\left(140^{\circ} \mathrm{C}, 2.3 \mathrm{~s}\right)$ or by HTST pasteurization $\left(78^{\circ} \mathrm{C}, 15 \mathrm{~s}\right)$, homogenized at $20.7 \mathrm{MPa}$, and stored at $4^{\circ} \mathrm{C}$ for 8 wk. Additionally, $2 \%$ fat milk was processed by indirect UP and homogenized at 13.8, 20.7 , and 27.6 MPa and stored at $4^{\circ} \mathrm{C}$ for 8 wk. Sensory profiling, instrumental viscosity, and friction profiles of all milk were evaluated at $25^{\circ} \mathrm{C}$ after storage times of 1,4 , and 8 wk. Sodium dodecyl sulfate PAGE and confocal laser scanning microscopy were used to determine protein structural changes in milk at these time points. Fresh HTST milk was processed at wk 7 for wk 8 evaluations. Ultrapasteurization increased milk sensory and instrumental viscosity compared with HTST pasteurization. Increased fat content increased sensory and instrumental viscosity, and decreased astringency and friction profiles. Astringency, mixed regimen friction profiles, and sensory viscosity also increased for UP versus HTST. Increased storage time showed no effect on sensory viscosity or mechanical viscosity. However, increased storage time generally resulted in increased friction profiles and astringency. Sodium dodecyl sulfate PAGE and confocal laser scanning microscopy showed increased denatured whey protein in UP milk compared with HTST milk. The aggregates or network formed by these proteins and casein micelles

Received July 25, 2017.

Accepted November 21, 2017

${ }^{1}$ Corresponding author: hjoyner@uidaho.edu likely caused the increase in viscosity and friction profiles during storage. Homogenization pressure did not significantly affect friction behaviors, mechanical viscosity, or astringency; however, samples homogenized at 13.8 $\mathrm{MPa}$ versus 20.7 and 27.6 $\mathrm{MPa}$ showed higher sensory viscosity. Astringency was positively correlated with the friction coefficient at $100 \mathrm{~m} / \mathrm{s}$ sliding speed $\left(\mathrm{R}^{2}=0.71\right.$ for HTST milk and $\mathrm{R}^{2}=0.74$ for UP milk), and sensory viscosity was positively correlated with the mechanical viscosity at a shear rate of $50 \mathrm{~s}^{-1}\left(\mathrm{R}^{2}=\right.$ 0.90). Thus, instrumental testing can be used to indicate certain sensory behaviors of milk.

Key words: milk, sensory, rheology, tribology, pasteurization

\section{INTRODUCTION}

The oral texture of food is thought to be related closely to overall food liking (de Wijk and Prinz, 2006). Once placed in the mouth, food is subjected to a complex series of oral processes that are related to perceived texture (Lenfant et al., 2009). For solid food, physical deformation and breakdown properties are related to sensory attributes such as hardness, softness, plasticity, crispness, brittleness, and sponginess (Sherman, 1969, Agrawal et al., 1997). As oral processing continues, more saliva is added and attributes related to physical structure (e.g., smoothness, lumpiness, and pastiness), consistency (e.g., creaminess and wateriness), and adhesion to the palate (e.g., stickiness) are perceived (de Wijk and Prinz, 2006). Oral processing of liquid food is less complicated, which results in liquid food sensory attributes being dominated by flow behaviors (Engelen and de Wijk, 2012). However, some sensory attributes that persist after swallowing, termed "afterfeel," depend on thin-film tribology behaviors (Chen and Stokes, 2012).

Astringency, a common after-feel sensation, is related to food residue following consumption (Stokes et al., 2013). Substances that cause an astringent sensation, 
such as alum, tannins, and some polyphenols, are called astringent molecules (Green, 1993). The popular mechanism of astringency is believed to be the result of aggregation and precipitation of salivary proteins, which causes the loss of saliva lubrication ability (Jöbstl et al., 2004). The precipitation of salivary proteins caused by astringent molecules produces a dry feeling in the mouth through gritty feeling or interruption of the salivary film (Gibbins and Carpenter, 2013). However, Rossetti et al. (2009) found epicatechin was unable to precipitate saliva proteins but caused astringency mouthfeel similar to epigallocatechin gallate (EGCG), which did precipitate salivary proteins when used at the same concentration (Rossetti et al., 2009). On the other hand, semi-skimmed milk-EGCG solutions were perceived as less astringent than the EGCG solution alone, although both solutions induced loss of lubrication in saliva-coated surfaces (Rossetti et al., 2009). Thus, a direct relationship between precipitation of saliva proteins and astringency cannot be found for all astringent substances.

The specific mechanisms behind milk astringency have not received much attention in the literature. Increased astringency was also associated with increased particle size and heat-altered whey proteins (Josephson et al., 1967). On the other hand, milk astringency and the presence of $\gamma$-caseins were found to be related (Harwalkar et al., 1993). Withers et al. (2014) found that caseins bound more strongly to oral surfaces than $\beta$-lactoglobulin. However, several studies by these authors suggested that both casein and whey proteins contributed to milk astringency (Withers et al., 2013, 2014). Although milk astringency is clearly related to changes to milk proteins, a consensus has not been achieved on which specific proteins and changes contribute to milk astringency.

The presence of fat has a significant effect on perceived astringency. Astringent and friction-related sensations can be reduced by coating the oral surfaces with fat (de Wijk and Prinz, 2005, 2006; des Gachons et al., 2012). Perceived astringency in custards (de Wijk and Prinz, 2005, 2006), spreadable cheeses (Bayarri et al., 2011), and ice cream (Soukoulis et al., 2010) has been shown to decrease with increased fat content. On the other hand, fat content has not been shown to significantly affect milk astringency (Phillips et al., 1995; Campbell et al., 2003; Ares et al., 2009). However, these studies generally used samples with lower fat content $(\leq 2 \%)$; a higher fat content may be needed to affect astringent sensations. One study did use milk with a fat content of $3.2 \%$ and showed that it had equal ability to reduce astringent sensation of antioxidant extracts as skim milk (Ares et al., 2009). Viscosity may play a role in the ef- fect of fat on perceived astringency: studies that found that fat content affected astringency used foods with viscosities that were significantly higher than milk. In foods with lower viscosity, a higher fat content may be needed to achieve a reduction in perceived astringency because the lower viscosity food would be easier to remove from the oral surfaces and thus have reduced protection against astringent compounds.

Clearly, astringency is a complex sensory attribute and has multiple mechanisms. A significant number of studies have been done on astringency of wine and tea because they are commonly known to be astringent. Other astringent foods have received little attention in the literature. For example, ultrapasteurization (UP) of milk can increase the shelf life of milk compared with HTST pasteurization; however, UP milk is perceived as more astringent (Datta et al., 2002; Lee et al., 2017). The increase in astringency, as well as other sensory and physicochemical changes such as cooked flavor, and bitterness, color change, protein sediment, and age gelation, is due to the more severe thermal treatment in UP versus HTST (Datta et al., 2002). However, the published literature does not explain the astringency mechanism in UP milk. It is possible that the mechanism is related to increased whey protein denaturation from UP. Denatured whey proteins have an increased number of interactions with each other and caseins, and form large complexes that influence mouthfeel attributes (Morales et al., 2000). Thus, the objective of this study was to determine how fat content, pasteurization method, homogenization pressure, and storage time affect the sensory and mechanical properties of bovine milk.

\section{MATERIALS AND METHODS}

\section{Experimental Design}

Experiments were designed to determine the effect of different variables (fat content, storage time, pasteurization method, and homogenization pressure) on mechanical properties and sensory attributes and to determine how mechanical properties relate to sensory attributes in milk. Thus, skim (fat $<0.2 \%$ ), $2 \%$ fat, and $5 \%$ fat milk were used to study the influence of fat content on mechanical and sensory properties. Milk with different fat contents was pasteurized by HTST or UP-indirect method to determine the effect of pasteurization methods on mechanical and sensory properties. Three different homogenization pressure levels (13.8, 20.7, and 27.6 MPa) were used to study the effect of homogenization pressure on mechanical and sensory properties. Milk was stored at $4^{\circ} \mathrm{C}$ until tested for sen- 
sory and mechanical properties after storage periods of 1, 4, and 8 wk. Milk was processed at North Carolina State University (NCSU) in duplicate 2 mo apart, and each duplicate was tested in triplicate unless otherwise stated. Proximate analysis and sensory evaluation were performed at NCSU. Rheological, tribological, SDS-PAGE, and confocal laser scanning microscopy (CLSM) analyses were completed at the University of Idaho.

\section{Milk Processing}

Skimmed raw bovine milk (3.1\% protein, $0.06 \%$ fat) and raw cream (45.1\% fat) were obtained from the NCSU (Raleigh) dairy facility and pasteurized at NCSU. Raw milk was standardized to $2.0 \%$ (wt/wt) or $5.0 \%$ (wt/wt) fat using raw cream, and milks were processed using the procedures described by Lee et al. (2017). Briefly, for each batch of milk, 37.85 L of milk was pasteurized using a Microthermics EHVH pasteurization unit (Microthermics, Raleigh, NC) by indirect UP or HTST pasteurized followed by 2-stage homogenization (GEA Niro Soavi, Parma, Italy). Homogenized milk was cooled, packaged in 473-mL high-density polyethylene dairy bottles (Container \& Packaging Supply, Eagle, ID), and stored at $4^{\circ} \mathrm{C}$ for tests. Milk sensory viscosity, astringency, mechanical viscosity, and friction behaviors were evaluated 1,4 , and 8 wk after pasteurization. New HTST samples were processed 1 wk before testing at wk 8 due to shelf-life restrictions. After packaging, milk was shipped overnight under refrigeration $\left(4^{\circ} \mathrm{C}\right)$ to the University of Idaho (Moscow).

\section{Milk Samples Pasteurized by Different Heat Treatments}

For the HTST treatments, skim, and 2 and $5 \%$ fat content milk was preheated to $60^{\circ} \mathrm{C}$, homogenized, and pasteurized at $78^{\circ} \mathrm{C}$ for $15 \mathrm{~s}$, then cooled to $10 \pm 2^{\circ} \mathrm{C}$ using an indirect heat exchanger. Skim and 2 and 5\% fat content milk for UP were processed by preheating the raw milk to $90^{\circ} \mathrm{C}$, then pasteurizing in the indirect heat exchanger at $140^{\circ} \mathrm{C}$ for $2.3 \mathrm{~s}$. The milk was cooled to $85^{\circ} \mathrm{C}$ for homogenization, then cooled by a secondary cooler (plate heat exchanger) to $10 \pm 2^{\circ} \mathrm{C}$ before packaging. Both HTST and UP processes used water as heating and cooling medium in the indirect heat exchangers. All milk was homogenized at $20.7 \mathrm{MPa}$ total pressure with $3.4 \mathrm{MPa}$ on the second stage.

\section{Milk Samples Homogenized at Different Pressures}

The $2.0 \%$ fat content milk was processed by the indirect UP method described above. In the homogeniza- tion stage, pasteurized milk was cooled to $85^{\circ} \mathrm{C}$, then homogenized at a total pressure of $13.8 \mathrm{MPa}(2,000$ psi), 20.7 MPa (3,000 psi), or 27.6 $\mathrm{MPa}$ (4,000 psi) using 2-stage homogenization, then cooled by a secondary cooler to $10 \pm 2^{\circ} \mathrm{C}$ before packaging. The pressure of the second stage was $15 \%$ of the total pressure, which was $2.07 \mathrm{MPa}(300 \mathrm{psi}), 3.10 \mathrm{MPa}(450 \mathrm{psi}$ ), and $4.14 \mathrm{MPa}$ (600 psi), for 13.8, 20.7, and 27.6 MPa, respectively.

\section{Proximate Analysis}

Milk solids, fat, and protein contents were measured with a Fourier-transform infrared dairy analyzer (LactoScope FTIR, Delta Instruments BV, Drachten, the Netherlands). Testing was completed on each milk sample directly after pasteurization and samples were measured in duplicate. Complete pasteurization of each milk was confirmed by the alkaline phosphatase test (method 14.060; Wehr and Frank, 2004).

\section{Sensory Analysis}

Sensory attributes for evaluation of milk samples were conducted at NCSU in accordance with the NCSU Institutional Review Board regulations. Astringency and sensory viscosity were selected for evaluation based on published literature that suggested that astringency was friction related and thickness (sensory viscosity) was related to mechanical viscosity in other foods (de Wijk and Prinz, 2005).

A trained sensory panel ( $\mathrm{n}=7,6$ females, 1 male, ages 23-54 yr) was used to evaluate astringency and sensory viscosity between milk samples within each fat content or within different homogenization pressure at 1, 4, and 8 wk after processing. Each panelist had received previous training (a minimum of at least 50 h) with identification and scaling of astringency and viscosity consistent with the Spectrum descriptive analysis method (Meilgaard et al., 2007). Panelists also received specific instructions on the current test format and protocol. Forty milliliters of each milk was dispensed into lidded 59-mL soufflé cups (Dart Container Corp., Mason, MI) with random 3-digit blinding codes and tempered to $10^{\circ} \mathrm{C}$. Panelists used noseclips (Adinstruments, Colorado Springs, CO) while evaluating milk samples to mask other sensory attributes. Panelists were instructed to place approximately half of each sample in their mouths, hold for approximately 10 $\mathrm{s}$, and then expectorate. After evaluating each sample, they were asked to quantify the perceived intensity of astringency and viscosity attributes from 0 to 15 , where $0=$ attribute not detected and $15=$ attribute extremely strong. A 10-min rest was enforced between samples, and panelists rinsed with spring water followed by $0.1 \%$ 
wt/wt solution of carboxymethylcellulose (TIC Gums, White Marsh, MD) during the rest period. A digital ballot was used to collect the data (Compusense Cloud, Compusense Inc., Guelph, Canada).

\section{Viscometry}

Milk mechanical viscosity measurements were performed on a DHR-3 rheometer (TA Instrument, New Castle, DE) at $25^{\circ} \mathrm{C}$. A concentric cylinder geometry (28.04 $\mathrm{mm}$ bob diameter and $21.10 \mathrm{~mm}$ bob length) was used for testing. Milk was tested after 1, 4, and 8 wk of storage and 3 replicates were performed on each sample. For each replicate, an $8-\mathrm{mL}$ milk sample was pipetted into the $30-\mathrm{mm}$ diameter cup; this volume of milk was used because it completely covered the top of the bob. After equilibrating the sample at the testing temperature, the shear rate was increased logarithmically from 0.01 to $100 \mathrm{~s}^{-1}$.

\section{Tribometry}

Friction profiles of milk stored for 1, 4, and 8 wk were performed on a DHR-3 rheometer at $25^{\circ} \mathrm{C}$ with a rubbing contact consisting of a double-ball on plate geometry and a polydimethylsiloxane (PDMS) disk (40 mm diameter). All PDMS plates were made using a 2-component silicone elastomer kit (Dow Corning Corporation, Midland, MI) per the method of Bongaerts et al. (2007a). Both the PDMS disk and the balls used in measurement were selected to approximate the hardness of oral tissues. The double-ball geometry consisted of 2 polypropylene balls ( $15.88 \mathrm{~mm}$ diameter, McMaster-Carr, Elmhurst, IL) arranged so that their centers were $27 \mathrm{~mm}$ apart. A normal force of $1 \mathrm{~N}$ was selected for all friction measurements (Bongaerts et al., 2007b) and was based on an in-mouth force during swallowing of 0.01 to $10 \mathrm{~N}$ (Miller and Watkin, 1996). To mount the PDMS disk onto the rheometer base, the smooth face of a square of wax paper was adhered to the PDMS disk using silicone glue (DAP Product Inc., Baltimore, $\mathrm{MD})$. After the silicone glue was allowed to set at room temperature $\left(22 \pm 2^{\circ} \mathrm{C}\right)$ overnight, the rough face of wax paper was attached to the rheometer base with cyanoacrylate glue (Henkel Corporation, Rocky Hill, $\mathrm{CT}$ ). For each test, $1 \mathrm{~mL}$ of milk was spread on the PDMS disk in a thin layer. After the balls were lowered to the desired normal force, sliding speed was increased stepwise from 0.15 to $750 \mathrm{~mm} / \mathrm{s}$. Samples were tested in quadruplicate and balls and disks were changed every 4 samples to mitigate the effects of wear on test results.

To remove fat buildup on the tribological surfaces, both the balls and disk were cleaned with a $5 \%$ (vol/ vol) solution of dish soap (Procter \& Gamble, Cincinnati, $\mathrm{OH}$ ), followed by cleaning with $75 \%$ ethanol and laboratory wipes.

\section{SDS-PAGE}

The SDS-PAGE analyses were conducted with or without a reducing agent based on the method described by Havea et al. (1998) and Jovanovic et al. (2007). For nonreduced sample preparation, $5 \mu \mathrm{L}$ milk sample was diluted with $15 \mu \mathrm{L}$ of Laemmli (Bio-Rad Laboratories Inc., Hercules, CA) and $80 \mu \mathrm{L}$ of distilled water in a $2-\mathrm{mL}$ plastic tube. For reduced samples, 5 $\mu \mathrm{L}$ of milk was diluted with $15 \mu \mathrm{L}$ of Laemmli and 75 $\mu \mathrm{L}$ of distilled water mixed with $5 \mu \mathrm{L}$ of 2 -mercaptoethanol (Sigma-Aldrich, St. Louis, MO). Prepared samples were shaken for $10 \mathrm{~s}$ and incubated at $100^{\circ} \mathrm{C}$ for $5 \mathrm{~min}$, and $70 \mathrm{~mL}$ of $10 \times$ Tris/glycine/SDS buffer (Bio-Rad Laboratories Inc.) was diluted using $630 \mathrm{~mL}$ of deionized, distilled water. Samples were analyzed using a 4 to $15 \%$ precast polyacrylamide gel $(8.6 \times 6.7$ $\mathrm{cm}$, width $\times$ length; Bio-Rad Laboratories Inc.) and Mini-Protein Electrophoresis Cells (Bio-Rad Laboratories Inc.). Precision Plus Protein Dual Color Standards (Bio-Rad Laboratories Inc.) were used to identify the molecular weight of the detected proteins. Ten microliters of each sample was added into the injection port and run at $300 \mathrm{~V}$ for $15 \mathrm{~min}$. The gel was stained with the Coomassie Brilliant Blue staining solution (R-250; Bio-Rad Laboratories Inc.) for $90 \mathrm{~min}$, then destained in a methanol/acetic acid solution (10\% methanol, $40 \%$ acetic acid, $50 \%$ deionized water). Destained gels were scanned using GeneSys software (Syngene USA, Frederick, MD).

\section{Confocal Laser Scanning Microscopy}

Staining procedures and CLSM analysis were based on the method of Ong et al. (2010). Briefly, $10 \mathrm{~mL}$ of each milk was added to a solution of $4 \mathrm{mg}$ fast green (Sigma-Aldrich) in $150 \mu \mathrm{L}$ acetone (Sigma-Aldrich) to stain fat globules. After holding for $30 \mathrm{~min}$, a solution of $2 \mathrm{mg}$ of Nile red (TCI America, Portland, OR) in $150 \mu \mathrm{L}$ of acetone was added to the sample and held for another $30 \mathrm{~min}$ to stain milk proteins. Then, 100 $\mu \mathrm{L}$ of the stained sample was transferred to a cavity slide (BRAND, Wertheim, Germany) and covered with a glass coverslip with 2 drops of oil in the center of the coverslip. Samples were viewed at $22 \pm 2^{\circ} \mathrm{C}$ using a confocal laser scanning microscope (Olympus Corporation, Tokyo, Japan) equipped with an oil immersion $60 \times$ lens. Nile red was excited at a wavelength of 488 $\mathrm{nm}$ and fast green FCF at $633 \mathrm{~nm}$. 
Table 1. Composition of different milk samples ${ }^{1}$

\begin{tabular}{|c|c|c|c|}
\hline \multirow[b]{2}{*}{ Item } & \multicolumn{3}{|c|}{ Composition } \\
\hline & $\%$ Fat & $\%$ Protein & $\% \mathrm{TS}$ \\
\hline Skim milk & $0.08 \pm 0.01^{\mathrm{c}}$ & $3.32 \pm 0.01^{\mathrm{a}}$ & $9.32 \pm 0.02^{\mathrm{c}}$ \\
\hline $2 \%$ Fat milk & $2.05 \pm 0.01^{\mathrm{b}}$ & $3.27 \pm 0.02^{\mathrm{a}}$ & $11.12 \pm 0.31^{\mathrm{b}}$ \\
\hline $5 \%$ Fat milk & $5.02 \pm 0.01^{\mathrm{a}}$ & $3.21 \pm 0.01^{\mathrm{a}}$ & $14.28 \pm 0.26^{\mathrm{a}}$ \\
\hline $2 \%$ Fat milk- $13.8 \mathrm{MPa}$ & $1.96 \pm 0.01^{\mathrm{a}}$ & $3.23 \pm 0.02^{\mathrm{a}}$ & $10.95 \pm 0.31^{\mathrm{a}}$ \\
\hline $2 \%$ Fat milk-20.7 MPa & $1.97 \pm 0.01^{\mathrm{a}}$ & $3.22 \pm 0.02^{\mathrm{a}}$ & $10.97 \pm 0.22^{\mathrm{a}}$ \\
\hline $2 \%$ Fat milk-27.6 MPa & $1.96 \pm 0.01^{\mathrm{a}}$ & $3.23 \pm 0.02^{\mathrm{a}}$ & $10.98 \pm 0.26^{\mathrm{a}}$ \\
\hline
\end{tabular}

\section{Fat Globule Size Measurement}

The fat globule size of different pressure homogenized milk was measured using NIS Elements Viewer software (Nikon Corporation, Tokyo, Japan). For each sample, 3 pictures at different depth with good focusing were selected to measure the mean diameter of fat globules. To better measure fat globule size, fat globules with circularity $<0.50$ were removed. Mean diameter was calculated by the average of the fat globule sizes in these 3 measurements.

\section{Data Analysis}

Tribological data were graphed using Origin 8 (OriginLab, Northampton, MA). Standard deviations were calculated for all data and used as a basis for error bars on all graphs shown in the Results and Discussion section. Tribology profiles were analyzed for statistical difference by using error bars as an indication. If error bars at each point among different treatments showed no overlap, the points were considered significantly different. Because the mechanical viscosity of measured milk samples showed Newtonian liquid behavior, viscosity data at a shear rate of $50 \mathrm{~s}^{-1}$, the approximate shear rate of swallowing (Morris 1983), were used for analysis. Both mechanical viscosity data and sensory data were analyzed by 1-way ANOVA followed by Tukey's comparison using Minitab (Minitab Inc., State College, PA; $\alpha=0.05$ ). Mechanical viscosity was also analyzed by 2 -way ANOVA using Minitab $(\alpha=0.05)$. Fat globules size of different pressure homogenized milk were analyzed by one-way ANOVA followed by Tukey's comparison using Minitab $(\alpha=0.05)$. Regression analysis was completed using Minitab to study the correlations between astringency score and friction coefficient at sliding speed of $100 \mathrm{~mm} / \mathrm{s}$, and correlations between sensory viscosity score and mechanical viscosity at shear rate of $50 \mathrm{~s}^{-1}$.

\section{RESULTS}

\section{Milk Components}

Results of the proximate analysis are shown in Table 1. Percent solids significantly increased with significantly increased fat content, as expected. No other significant differences in proximate composition were detected. Homogenization pressure did not affect proximate composition $(P>0.05)$. All milks were negative for alkaline phosphatase, indicating complete pasteurization.

\section{Rheological Properties}

Mechanical viscosity measured at $50 \mathrm{~s}^{-1}$ of milk processed by different pasteurization methods are shown in Table 2. In general, indirect UP milk had insignificantly higher mechanical viscosity compared with HTST-pasteurized milk. Fat content significantly increased milk viscosity. The $5 \%$ fat milk had significantly higher viscosity than $2 \%$ fat and skim milk; $2 \%$ fat milk viscosity was not significantly different from that of skim milk. The viscosity of UP skim milk did not change significantly with increased storage time. Mechanical viscosity profiles of different pressure homogenized $2 \%$ fat content milk are shown in Table 3. At all time points, no significant differences were observed in viscosity among milk samples homogenized at different pressures. Twoway ANOVA showed that pasteurization method and storage time had a significant interaction $(P<0.05)$.

\section{Tribological Properties}

Friction profiles of milk processed under different heat treatments and different homogenized pressures are shown in Figures 1 and 2, respectively. In general, UP increased friction profiles of milk in the mixed regimen compared with HTST pasteurization except for skim and 5\% fat milk at wk 1 and $5 \%$ fat milk 
Table 2. Mechanical viscosity $(\mathrm{mPa} \cdot \mathrm{s})$ measured at $50 \mathrm{~s}^{-1}$ of milk processed by different pasteurization methods ${ }^{1}$

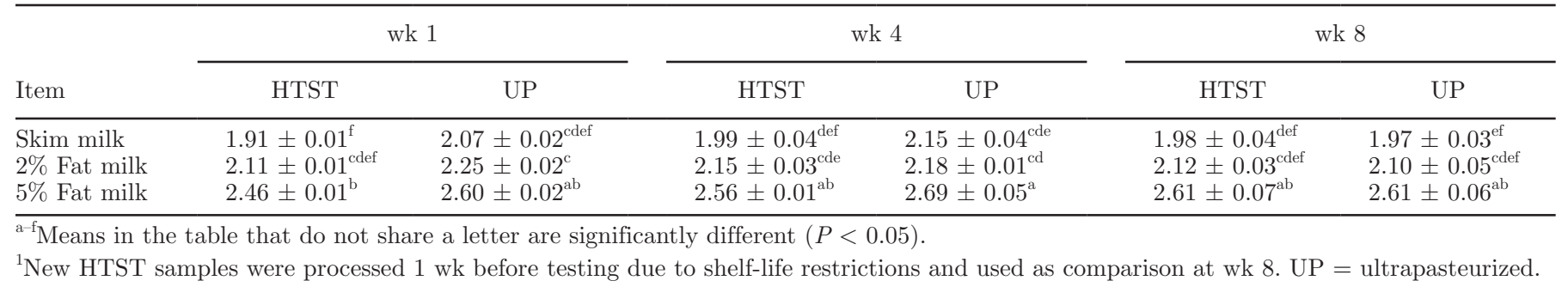

at wk 8, which had no significant differences between different heat treatments. Fat content significantly decreased milk friction profiles in the mixed regimen for all samples regardless of heat treatment or storage time. The UP skim milk showed significantly higher friction profiles in the mixed regimen at wk 4 and 8 compared with wk 1. The HTST-pasteurized $5 \%$ fat milk showed significantly higher friction profiles in the mixed regimen at wk 8 compared with wk 1 and 4 . Otherwise, storage time had no significant effect on friction profiles. No significant differences were found among friction profiles of milk homogenized at different pressures for any time point.

\section{Sensory Properties}

The effect of pasteurization method, fat content, storage time, and homogenization on sensory viscosity and astringency results are shown in Figures 3, 4, 5, and 6 , respectively. In general, increased fat content significantly increased sensory viscosity and significantly decreased astringency. Storage time significantly increased UP milk astringency; however, it showed no effect on HTST-pasteurized milk astringency. We observed no significant differences among sensory viscosities of milk at different storage times with 2 exceptions. First, $2 \%$ fat milk at wk 8 showed significantly lower sensory viscosity than wk 1 and 4 for both UP and HTST milk. Additionally, 5\% fat milk at wk 4 showed significantly higher sensory viscosity than wk 1 and 8 for UP milk. Compared with HTST pasteurization, UP significantly increased sensory viscosity except for skim milk at wk 1 and 4 , and $2 \%$ fat milk at wk 8 . The UP significantly increased astringency with the exception of $2 \%$ fat milk at wk 1 and $5 \%$ fat milk at wk 1 and 4. Milk homogenized at $13.8 \mathrm{MPa}$ showed significantly higher sensory viscosity than milk homogenized at 20.7 and 27.6 MPa. However, homogenization pressure had no effect on astringency.

\section{CLSM Results}

Microscopy images of the milk protein structure are shown in Figure 7; the bright green spots are casein micelles. In HTST-pasteurized milk (Figure 7a, 7b, 7c), the casein micelles were randomly distributed. However, after UP (Figure 7d, 7e, 7f), casein micelles in milk were likely to build a protein network structure by linking denatured whey proteins (McMahon, 1996), which was not seen in HTST milk.

Microscopy images of the milk fat distribution are shown in Figure 8; the red spots are fat droplets. In general, fat droplet sizes were relatively uniform at each homogenization pressures of 13.8, 20.7, and 27.6 MPa. The mean diameter of homogenized milk fat globules was between $0.92 \pm 0.07$ to $0.98 \pm 0.08 \mu \mathrm{m}(13.8 \mathrm{MPa})$, $0.90 \pm 0.05$ to $0.99 \pm 0.09 \mu \mathrm{m}(20.7 \mathrm{MPa})$, and 0.87 \pm 0.03 to $0.93 \pm 0.02 \mu \mathrm{m}(27.6 \mathrm{MPa})$. No significant differences $(P>0.05)$ were found in mean diameter of fat globules between different pressure homogenized milk at different time points (Table 4).

\section{SDS-PAGE Results}

The SDS-PAGE results are shown in Figure 9. In UP milk (lanes 2, 4, and 6), the amount of whey protein with a molecular weight $<15 \mathrm{kDa}$ was small compared with HTST-pasteurized milk (lanes 1, 3, and 5). How-

Table 3. Mechanical viscosity ( $\mathrm{mPa} \cdot \mathrm{s}$ ) measured at $50 \mathrm{~s}^{-1}$ of $2 \%$ fat ultrapasteurized (UP) milk homogenized under different pressures

\begin{tabular}{lccc}
\hline Homogenization pressure $(\mathrm{MPa})$ & wk 1 & wk 4 & wk 8 \\
\hline 13.8 & $2.24 \pm 0.02^{\mathrm{a}}$ & $2.24 \pm 0.01^{\mathrm{a}}$ & $2.20 \pm 0.02^{\mathrm{a}}$ \\
20.7 & $2.20 \pm 0.01^{\mathrm{a}}$ & $2.27 \pm 0.01^{\mathrm{a}}$ & $2.18 \pm 0.01^{\mathrm{a}}$ \\
27.6 & $2.22 \pm 0.01^{\mathrm{a}}$ & $2.23 \pm 0.01^{\mathrm{a}}$ & $2.25 \pm 0.04^{\mathrm{a}}$ \\
\hline
\end{tabular}

${ }^{\mathrm{a}}$ Means in the table that do not share a letter are significantly different $(P<0.05)$. 

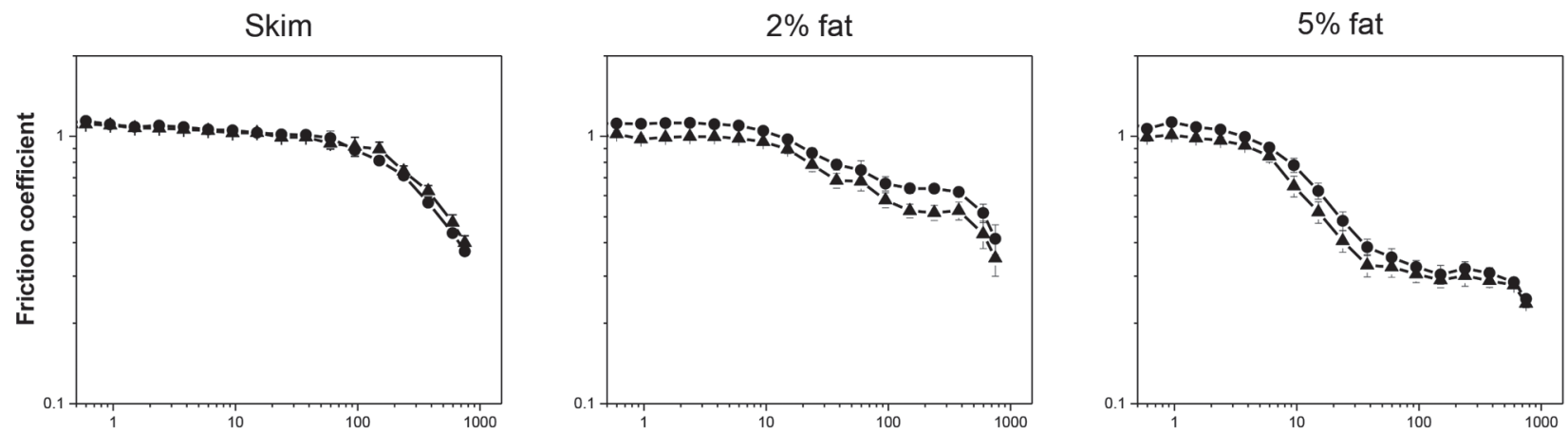

Week 1
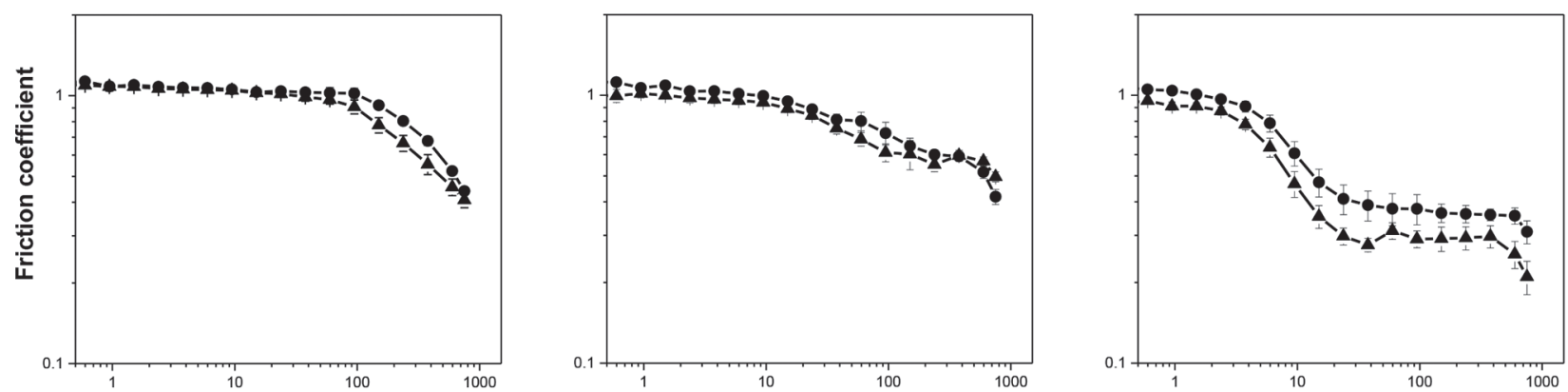

Week 4
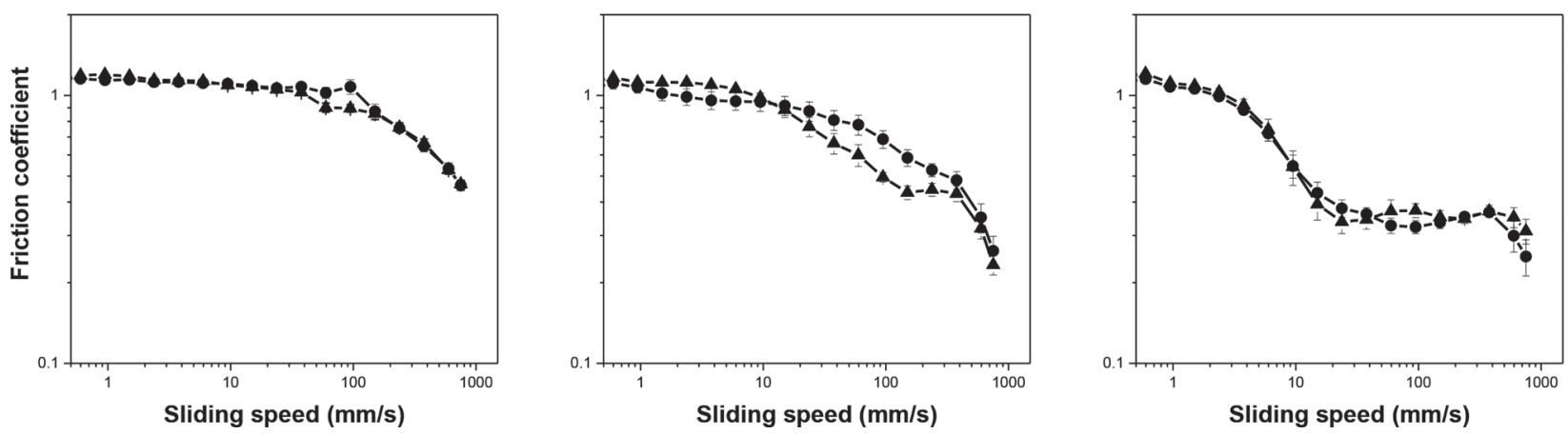

Week 8

Figure 1. Friction profiles of milk processed by different pasteurization methods. New HTST samples were processed 1 wk before testing due to shelf-life restrictions and used as comparison at wk 8 .

Week 1

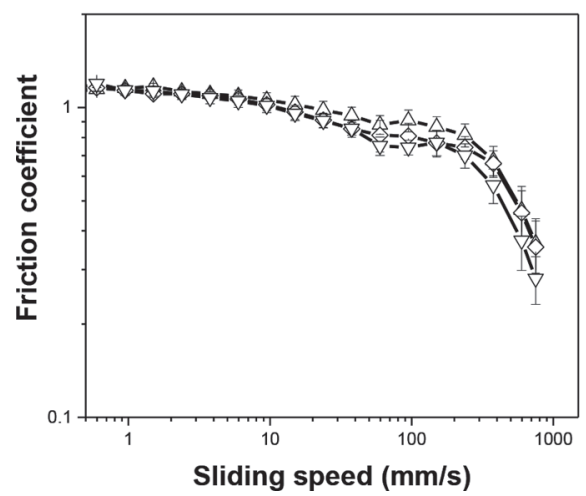

Week 4

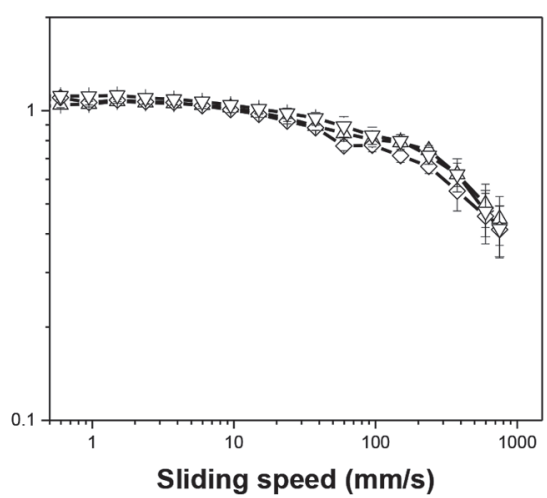

Week 8

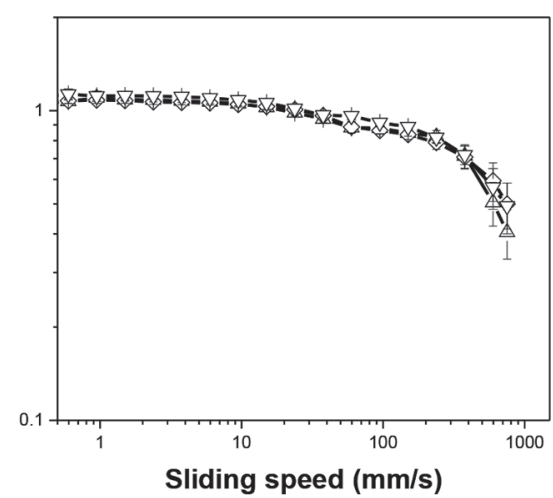

Figure 2. Friction profiles of ultrapasteurized $2 \%$ fat milk processed under different homogenization pressures. Right-side-up triangles denote samples processed at $13.8 \mathrm{MPa}$, diamonds denote samples processed at $20.7 \mathrm{MPa}$, and upside-down triangles denote samples processed at 27.6 MPa. Error bars represent SE. 
ever, UP milk samples showed proteins with molecular weight $>250 \mathrm{kDa}$ at the injection port. These large molecular weight proteins did not appear in HTSTpasteurized milk samples. However, after adding a reducing agent to the UP milk (lanes 7, 8, and 9), these large molecular weight proteins disappeared, and the small molecular weight $(<15 \mathrm{kDa})$ whey proteins reappeared, suggesting that the large molecular proteins were formed by denatured whey proteins via disulfide bonding.
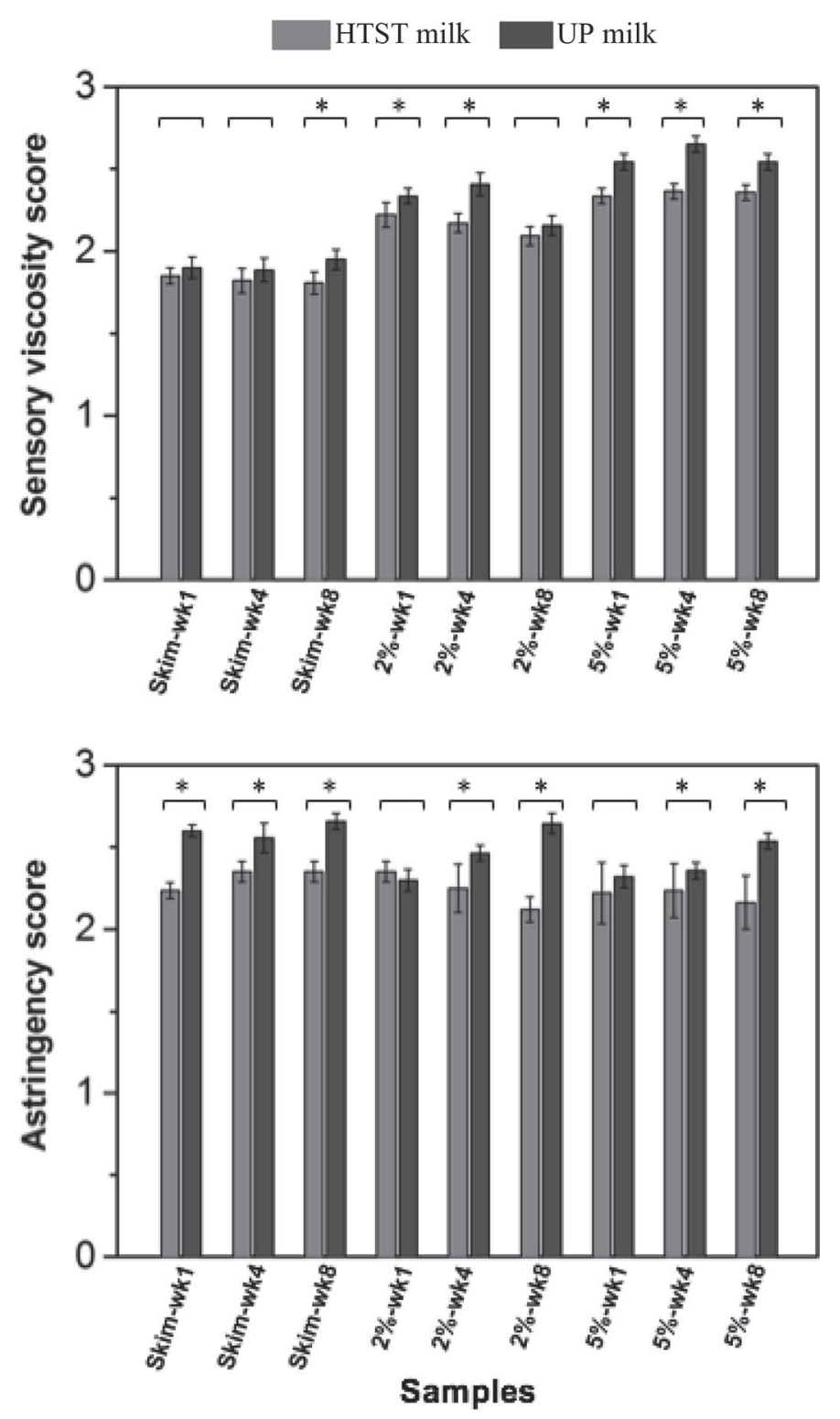

Figure 3. Comparison of sensory viscosity and astringency results of milk processed by different pasteurization methods. * represents significant differences $(P<0.05)$ in each pair. New HTST samples were processed $1 \mathrm{wk}$ before testing due to shelf-life restrictions and used as comparison at wk 8. UP = ultrapasteurized. Error bars represent SE.
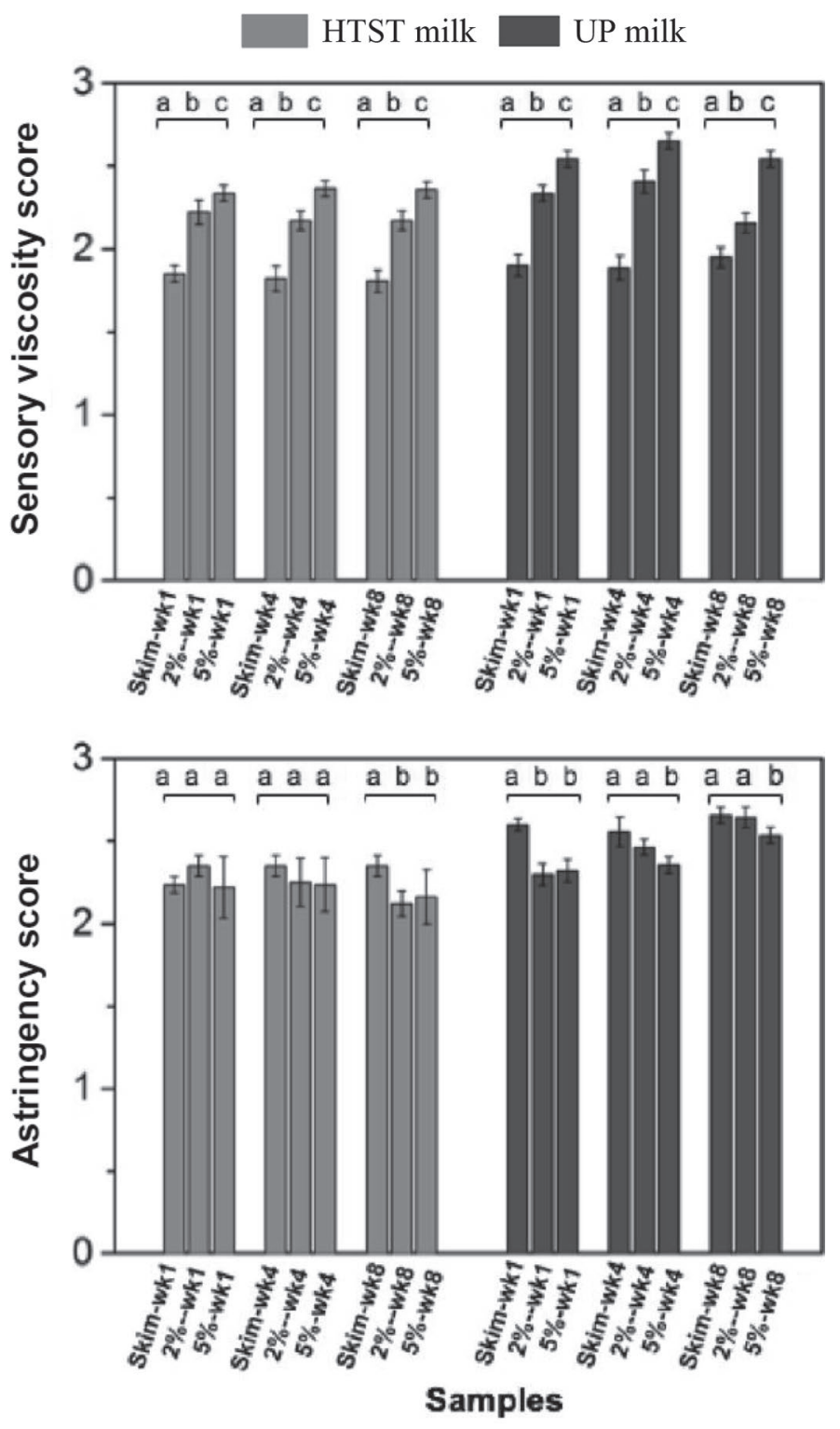

Figure 4. Comparison of sensory viscosity and astringency results of milk with different fat content. Different letters represent significant differences $(P<0.05)$ in each grouping. New HTST samples were processed $1 \mathrm{wk}$ before testing due to shelf-life restrictions and used as comparison at wk 8. Attribute intensities were scored on a 0 - to 15-point universal intensity scale (Meilgaard et al., 2007). Milk attributes fall between 0 and 4 on this scale (Lee et al., 2017; McCarthy et al., 2017). UP = ultrapasteurized. Error bars represent SE.

\section{DISCUSSION}

Fat content had the largest effect on both sensory and mechanical properties. Increased fat significantly decreased astringency and friction coefficients and significantly increased both sensory and mechanical viscosity. A potential reason for the increase of viscosity was that the presence of larger number and size of fat globules in higher fat milk increased the resistance to 

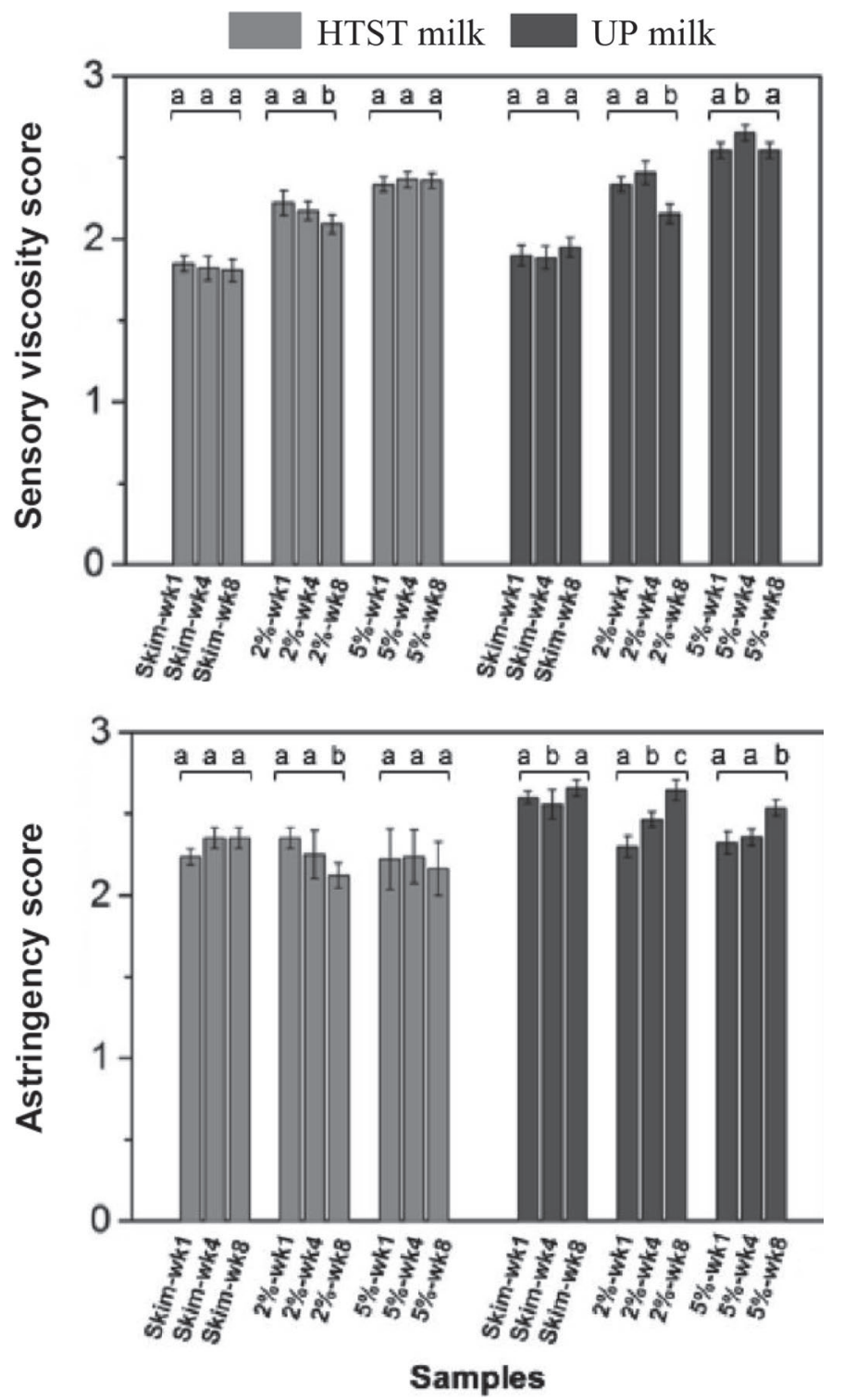

Figure 5. Comparison of sensory viscosity and astringency results of milk at different storage time points. Different letters represent significant differences $(P<0.05)$ in each grouping. New HTST samples were processed 1 wk before testing due to shelf-life restrictions and used as comparison at wk 8. Attribute intensities were scored on a 0to 15-point universal intensity scale (Meilgaard et al., 2007). Milk attributes fall between 0 and 4 on this scale (Lee et al., 2017; McCarthy et al., 2017). UP = ultrapasteurized. Error bars represent SE.

flow. The reason for the decrease of friction profiles is when the gap between polypropylene balls and PDMS disk is large enough to admit fat globules, the lubrication ability of fat could be applied. When fat content is high, more fat globules are present, increasing the amount of fat in the contact zone. Thus, milk with higher fat content showed lower friction coefficients in the mixed regimen and lower sliding speeds at the transition points from boundary regimen to mixed regimen.
Similarly, when more fat globules were present in the mouth, the fat globules reduced astringency by increasing lubrication and decreasing friction. McCarthy et al. (2017) compared sensory properties of HTST milks ranging from 0.10 to $6.6 \%$ fat and likewise noted that increased fat content increased sensory viscosity and decreased astringency.
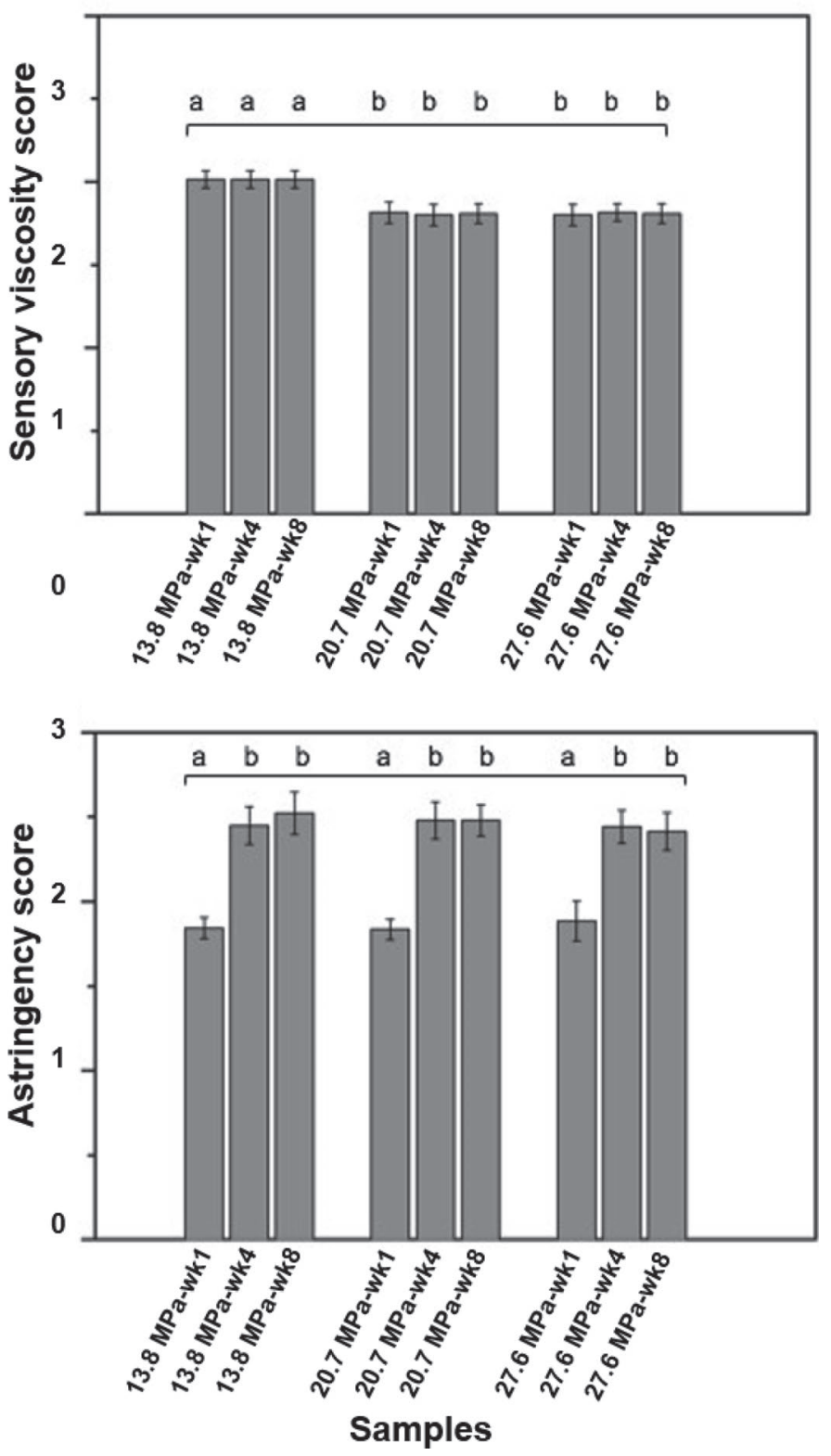

Figure 6. Comparison of sensory viscosity and astringency results of $2 \%$ fat ultrapasteurized milk homogenized at different pressures. Different letters represent significant differences $(P<0.05)$ in different groupings. Attribute intensities were scored on a 0 - to 15 -point universal intensity scale (Meilgaard et al., 2007). Milk attributes fall between 0 and 4 on this scale (Lee et al., 2017; McCarthy et al., 2017). Error bars represent SE. 
HTST
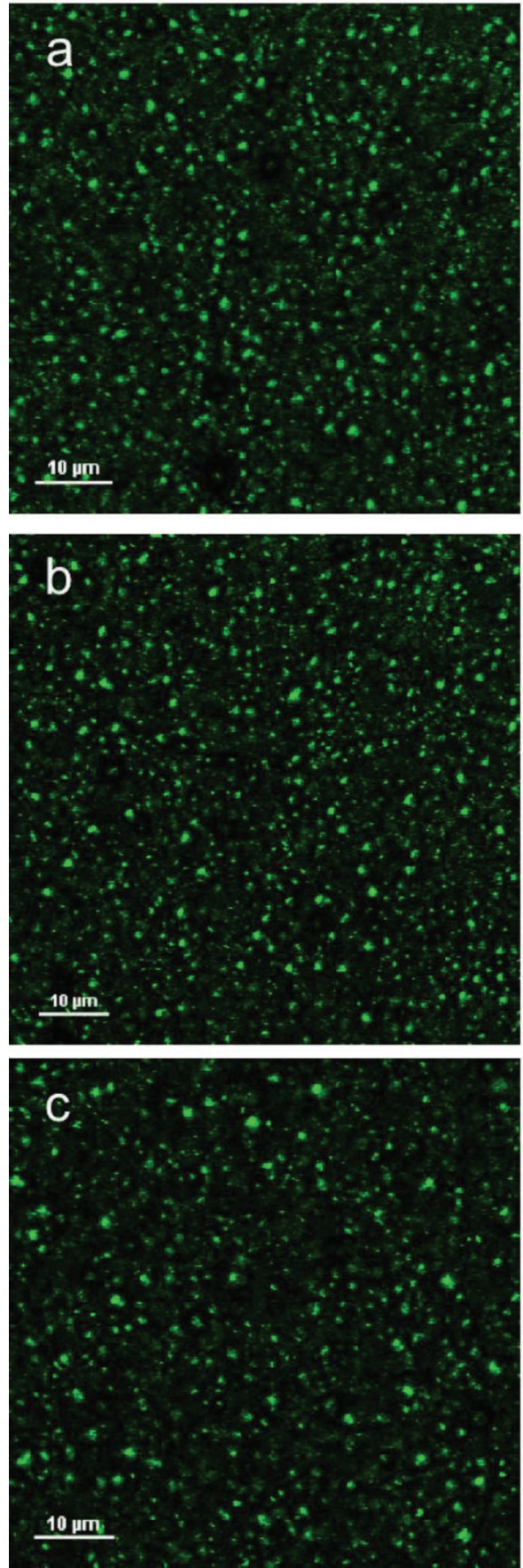

UP
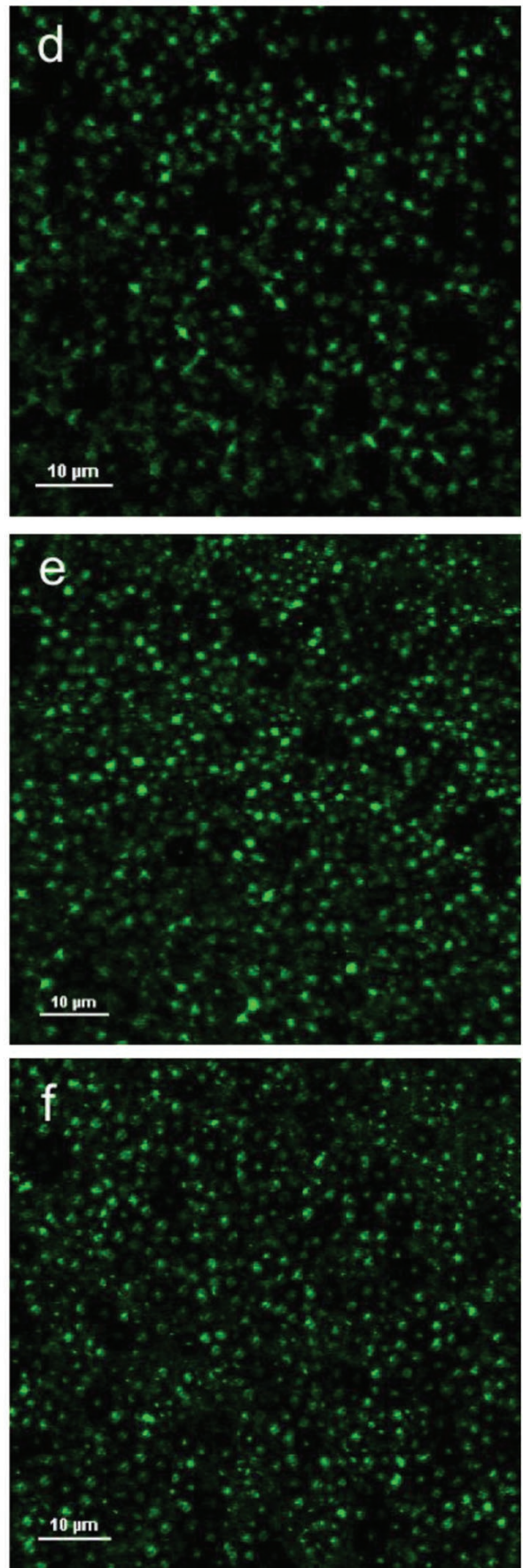

\section{Wk 1}

\section{Wk 4}

\section{Wk 8}

Figure 7. Confocal laser scanning microscopy images of protein structures for milk processed by different pasteurization methods. Milk proteins are shown in green (light color in print version). New HTST samples were processed $1 \mathrm{wk}$ before testing due to shelf-life restrictions and used as comparison at wk 8 . UP $=$ ultrapasteurized. Color version available online.

Beside fat content, heat treatment showed significant effect on milk sensory attributes and friction properties. Two-way ANOVA showed that heat treatment, storage time, and their interaction had a significant effect on mechanical viscosity (data not shown). Ultrapasteur- ized milk showed significantly higher sensory viscosities, astringency, and friction profiles in mixed regimen compared with HTST milk. Lee et al. (2017) also documented higher astringency in UP milk compared with HTST milk. However, no significant differences 
13.8 MPa
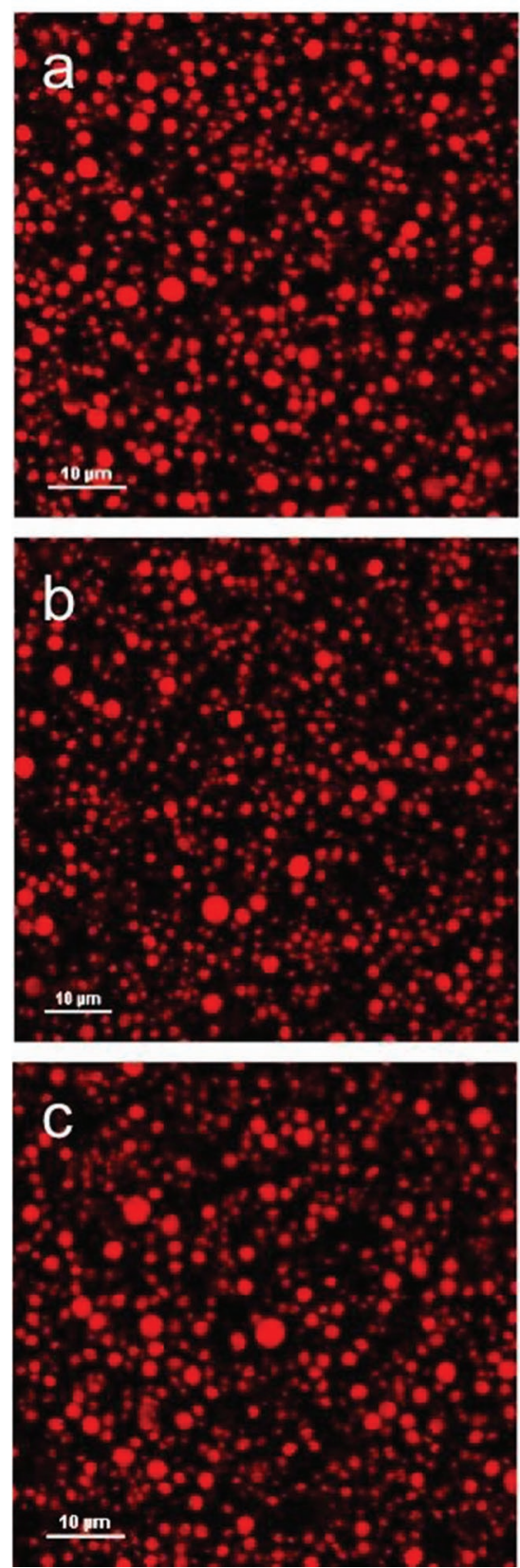

20.7 MPa
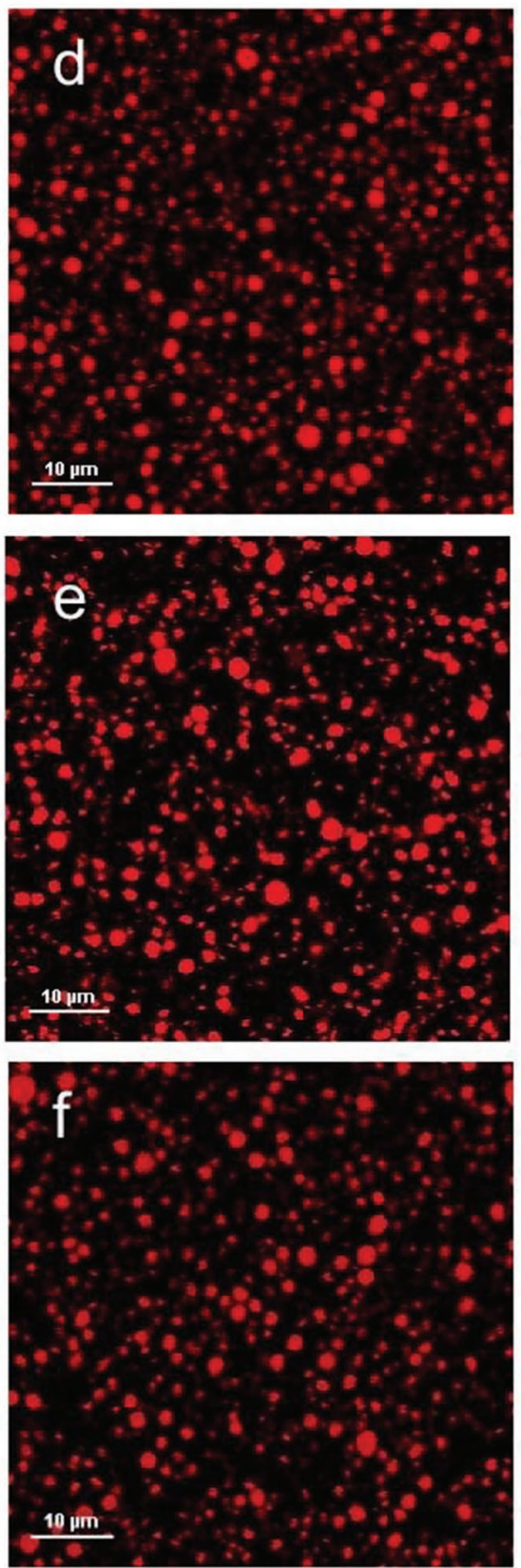

27.6 MPa

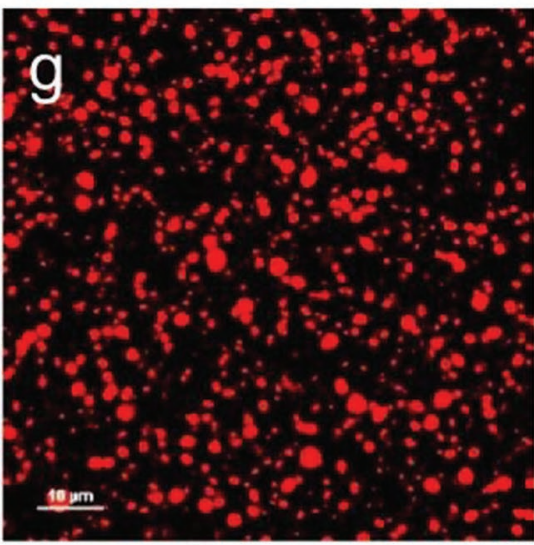

Wk 4
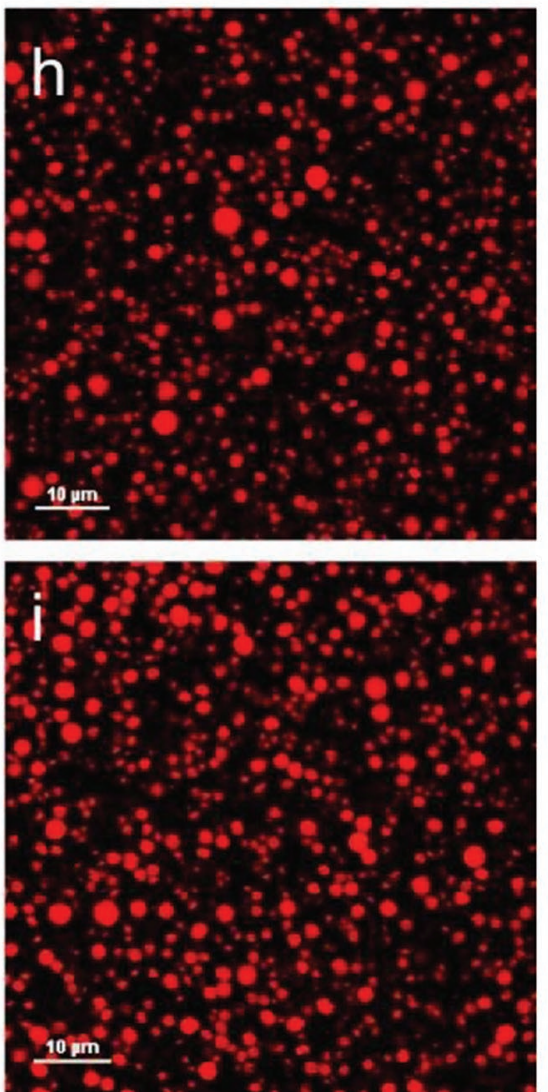

Wk 1

Wk 8

Figure 8. Confocal laser scanning microscopy images of fat globules for $2 \%$ fat milk homogenized at different pressures and stored for different time periods. Milk fat droplets are shown in red (light color in print version). Color version available online.

Table 4. Mean diameter of fat globules in $2 \%$ fat ultrapasteurized (UP) milk homogenized under different pressures

Mean diameter $(\mu \mathrm{m})$

\begin{tabular}{lccc}
\cline { 2 - 4 } Homogenization pressure (MPa) & wk 1 & wk 4 & wk 8 \\
\hline 13.8 & $0.98 \pm 0.08^{\mathrm{a}}$ & $0.92 \pm 0.07^{\mathrm{a}}$ & $0.97 \pm 0.02^{\mathrm{a}}$ \\
20.7 & $0.90 \pm 0.05^{\mathrm{a}}$ & $0.99 \pm 0.09^{\mathrm{a}}$ & $0.91 \pm 0.05^{\mathrm{a}}$ \\
27.6 & $0.88 \pm 0.02^{\mathrm{a}}$ & $0.87 \pm 0.03^{\mathrm{a}}$ & $0.93 \pm 0.02^{\mathrm{a}}$ \\
\hline
\end{tabular}

${ }^{\mathrm{a}}$ Means in the table that do not share a letter are significantly different $(P<0.05)$. 
were observed in mechanical viscosity. We hypothesized that these results were related to the protein structure changes in UP milk based on the denaturation mechanism of whey proteins and aggregation between denatured whey proteins and casein micelles (Anema and Li, 2003; Donato and Guyomarc'h, 2009).

Whey proteins were clearly present in HTST milk samples as dark bands in the 10 to $15 \mathrm{kDa}$ range (Figure 9). However, these bands were much fainter in UP milk samples, which indicated that most of the whey proteins were denatured by UP. These denatured whey proteins formed very large molecular proteins with molecular weight $>250 \mathrm{kDa}$. This result was consistent with the former study of Tran et al. (2008) that indirect UP causes 98 to $100 \%$ denaturation of $\beta$-LG and $74 \%$ denaturation of $\alpha$-LA, whereas HTST pasteurization only denatures 5 to $15 \%$ of $\beta$-LG (Griffiths, 2010). It also agreed with the results of Lee et al. (2017), who reported approximately $20 \%$ serum protein denaturation from HTST milk and approximately $70 \%$ from UP milk. The unfolding of whey proteins exposes the thiol/disulfide groups, which can be further used to form aggregates between denatured whey proteins through covalent bonds (Lyster, 1964). These $\beta-L G / \alpha-$ LA aggregates would further interact with $\kappa$-casein on the surface of casein micelle through disulfide bonding
(Donato and Guyomarc'h, 2009). Our results agreed with this theory: after addition of 2-mercaptoethanol, a reducing agent that opens disulfide bonds, the large molecular weight proteins disappeared and a band of proteins with molecular weight of $<15 \mathrm{kDa}$ appeared, indicating that the large molecular weight proteins were aggregated whey proteins.

We hypothesized that the large molecular weight protein is the cause of the increase of viscosity and friction profiles. The higher viscosity likely resulted from increased entanglements and stronger intermolecular forces in the larger molecules. Stronger intermolecular forces would result in greater attractions between molecules, hindering molecular flow and resulting in higher viscosity. de Wijk and Prinz (2006) proposed that particle size plays an important role in astringency: larger particles enhance astringency by reducing lubrication and increasing friction. Our study supported this mechanism. During storage, the denatured whey proteins in UP milk can form aggregates. From the astringency results, we observed that storage time did not affect HTST-pasteurized milk astringency; however, UP milk astringency significantly increased during storage. This supported the hypothesis that the cause of higher astringency was due to aggregates or a protein network formed by denatured whey proteins and caseins over

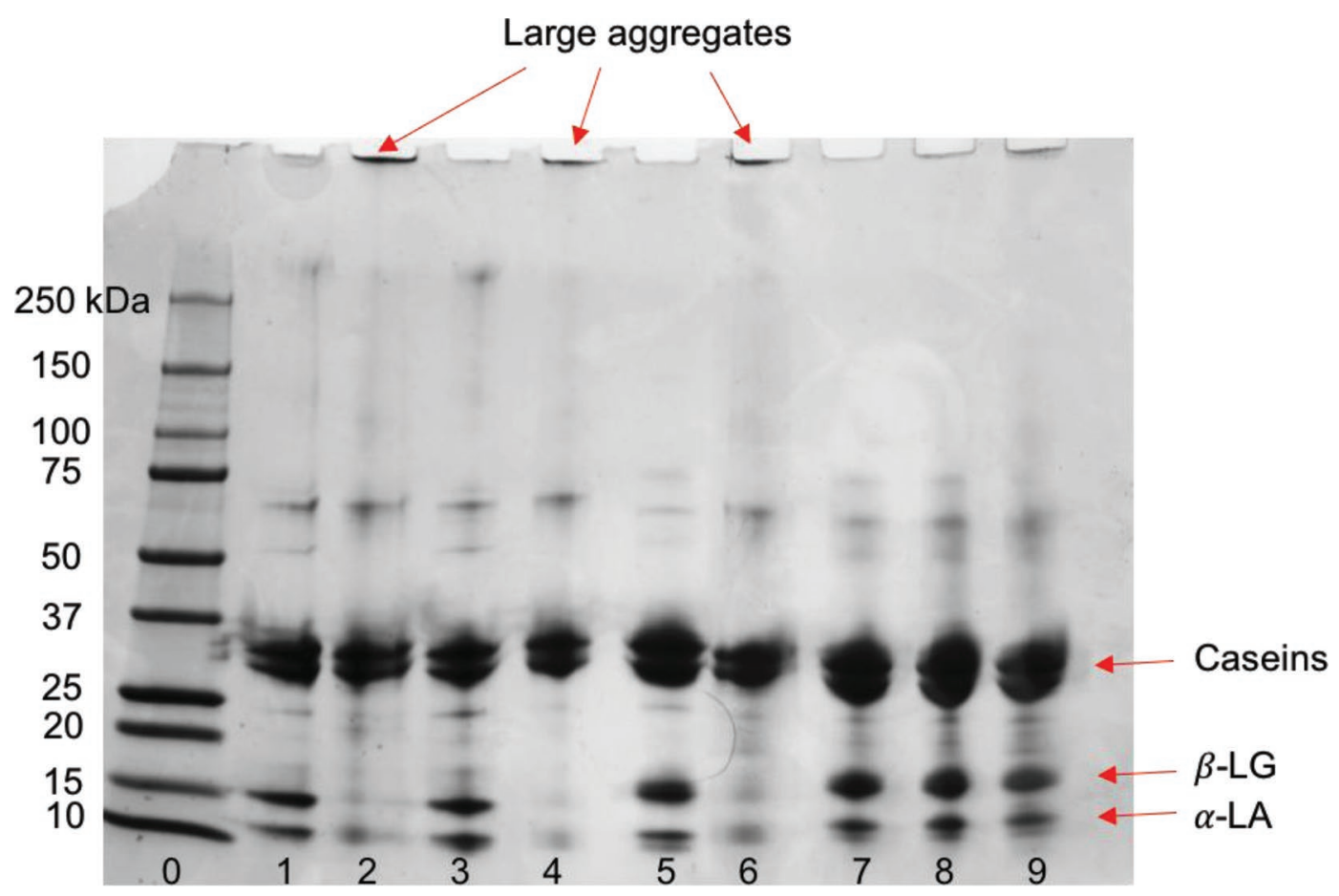

Figure 9. Sodium dodecyl sulfate PAGE results. Lane numbers (0-9) represent the following: (0) standards, (1) HTST milk at wk 1, (2) ultrapasteurized (UP) milk at wk 1, (3) HTST milk at wk 4, (4) UP milk at wk 4, (5) HTST milk at wk 8, (6) UP milk at wk 8, (7) UP milk at wk 1 with reducing agent, (8) UP milk at wk 4 with reducing agent, and (9) UP milk at wk 8 with reducing agent. New HTST samples were processed 1 wk before testing due to shelf-life restrictions and used for comparison at wk 8 . Color version available online. 
time. Our 2-way ANOVA results that showed an interaction between pasteurization and storage time for the viscosity results also support this hypothesis: the different structural changes become more apparent over time. Storage time did not affect the mean diameter of fat globules; thus, the increase of astringency was not a result of changes in fat globule size.

At homogenization pressures of 13.8 to $27.6 \mathrm{MPa}$, the influence of homogenization pressure on fat droplet size was not significant (Table 4). We hypothesized that this result was due to the high efficiency of 2-stage homogenization. In the selected range of homogenization pressure, higher pressure did not significantly reduce fat globule size. These results were supported by Hayes and Kelly's study on bovine milk: milk homogenized in a 2-stage process at $50 \mathrm{MPa}$ did not have significantly different fat globule diameters than milk homogenized at $18 \mathrm{MPa}$ (Hayes and Kelly, 2003). Compared with milk processed under 1-stage homogenization, which showed formation of fat globule clusters during storage, milk processed under 2-stage homogenized showed fewer clusters of fat globules during storage (Thiebaud et al., 2003). It is likely that 2-stage homogenization reduces fat droplets to a size at which they were not likely to coalesce over time and what pressure was used in 2-stage homogenization was not as important as the presence of the second stage. This was in agreement with our study, which showed no significant effect of homogenization pressure on mechanical and sensory properties.

The homogenization pressures studied also had no discernable effect on protein, as determined by no significant change in viscosity, friction behaviors, and microscopy images both across pressure and over time. While pressure is known to denature milk proteins (Pandey et al., 2000; López-Fandiño et al., 2006; Anema, 2008) and subsequently alter the physicochemical and mechanical properties of the milk system (Anema, 2008; Cadesky et al., 2017), the majority of the work on the effect of pressure on milk proteins involves holding the milk at high pressures (100-1,000 MPa) for 5 to 110 min (Pandey et al., 2000; Anema, 2008; Bravo et al., 2015; Cadesky et al., 2017). Homogenization, however, exposes milk to high pressures for much shorter times, on the order of seconds. Thus, it is likely that there was not sufficient time for the homogenization pressure to alter milk protein structures in this study.

Overall, fat content had a greater effect on sensory viscosity and astringency scores than heat treatment, storage time, or homogenization pressure. These results point to the importance of milkfat on the texture of milk and similar dairy beverages. No interaction effects among fat content and the other variables were observed, indicating that fat alone is a powerful driver.
Nevertheless, it may be possible to promote fat-milk component (e.g., fat-protein) interactions to enhance the effects of fat in milk systems. Further work is needed to examine the effects of potential fat-milk component interactions on the sensory attributes of the final milk system.

Based on the regression analysis (Figures 10 and 11), we observed that sensory viscosity and mechanical viscosity at shear rate of $50 \mathrm{~s}^{-1}$ were positively correlated $\left(\mathrm{R}^{2}=0.90\right)$, as expected. Even though the correlation between astringency and friction coefficient at sliding speed of $100 \mathrm{~mm} / \mathrm{s}$ (mixed regimen) was not as good as the correlation between sensory and mechanical viscosity, we still observed a $\mathrm{R}^{2}=0.71$ for HTST milk (Figure 11a) and $R^{2}=0.74$ (Figure 11b) for UP milk. These results suggest that other factors such as saliva may play a role in the astringency sensation imparted by milk (Jöbstl et al., 2004) and the relationship between astringency and friction is more complicated than the relationship between sensory and mechanical viscosity.

\section{CONCLUSIONS}

Increased fat content increased both sensory and mechanical viscosity in UP and HTST-pasteurized milk because of increased resistance to flow imparted by the increased number of fat globules. Increased fat content also decreased astringency and friction profiles in the mixed regimen due to the lubrication ability of fat. Indirect UP increased sensory viscosity, astringency, and friction profiles in the mixed regimen compared with HTST pasteurization; these differences were attributed to the large protein aggregates or protein network formed by denatured whey protein and casein micelles. Increased storage time showed no effect on sensory viscosity but did increase astringency. However,

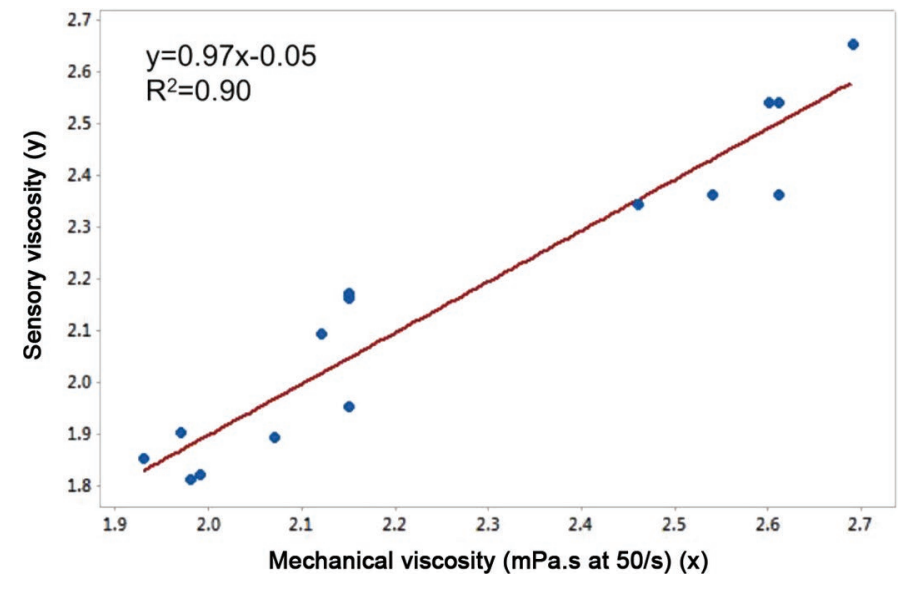

Figure 10. Correlations between sensory viscosity and mechanical viscosity. Color version available online. 

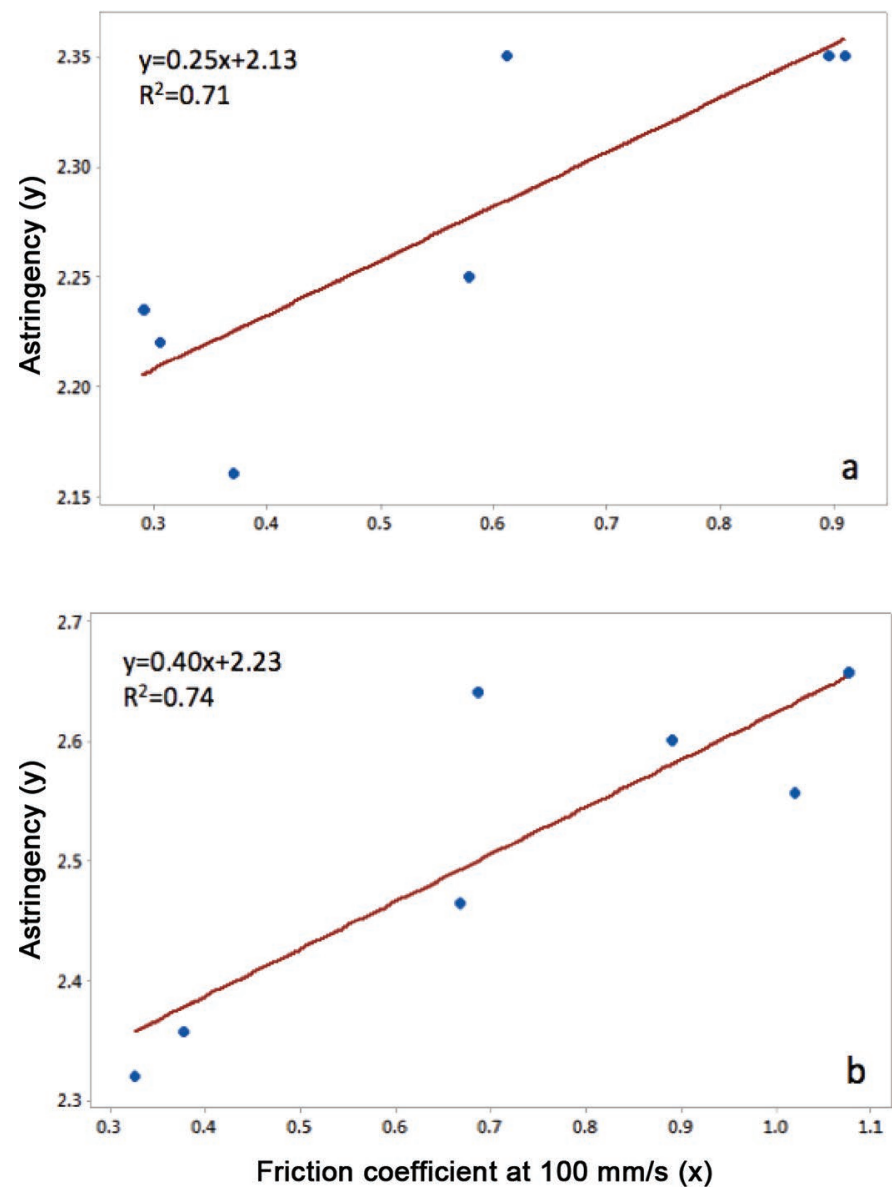

Figure 11. Correlations between astringency and friction coefficient. The top image represents HTST milk; the bottom image represents ultrapasteurized milk. Color version available online.

increased storage time caused an increasing trend in mechanical viscosity and friction profiles, likely due to time-dependent formation of protein aggregates and a protein network. Increased homogenization pressure decreased sensory viscosity; however, it had no effect on mean fat droplet size, sensory viscosity, astringency, or friction profiles. It is likely that $20.7 \mathrm{MPa}$ is sufficient pressure to homogenize milk fat droplets into a small enough diameter to provide stability over time. Overall, sensory viscosity correlated to mechanical viscosity at a shear rate of $50 \mathrm{~s}^{-1}$, whereas astringency correlated to the friction coefficient at a sliding speed of $100 \mathrm{~mm} / \mathrm{s}$ (mixed regimen).

\section{ACKNOWLEDGMENTS}

Funding for this project was provided by the Western Dairy Center's BUILD Dairy program (Utah State University, Logan) and the USDA National Institute of
Food and Agriculture (Washington, DC), Hatch project 1005029 .

\section{REFERENCES}

Agrawal, K. R., P. Lucas, J. Prinz, and I. Bruce. 1997. Mechanical properties of foods responsible for resisting food breakdown in the human mouth. Arch. Oral Biol. 42:1-9.

Anema, S. G. 2008. On heating milk, the dissociation of $\kappa$-casein from the casein micelles can precede interactions with the denatured whey proteins. J. Dairy Res. 75:415-421.

Anema, S. G., and Y. Li. 2003. Association of denatured whey proteins with casein micelles in heated reconstituted skim milk and its effect on casein micelle size. J. Dairy Res. 70:73-83.

Ares, G., C. Barreiro, R. Deliza, and A. Gámbaro. 2009. Alternatives to reduce the bitterness, astringency and characteristic flavour of antioxidant extracts. Food Res. Int. 42:871-878.

Bayarri, S., I. Carbonell, E. X. Barrios, and E. Costell. 2011. Impact of sensory differences on consumer acceptability of yoghurt and yoghurt-like products. Int. Dairy J. 21:111-118.

Bongaerts, J., K. Fourtouni, and J. Stokes. 2007a. Soft-tribology: Lubrication in a compliant PDMS-PDMS contact. Tribol. Int. 40:1531-1542.

Bongaerts, J., D. Rossetti, and J. Stokes. 2007b. The lubricating properties of human whole saliva. Tribol. Lett. 27:277-287.

Bravo, F. I., X. Felipe, R. López-Fandiño, and E. Molina. 2015. Skim milk protein distribution as a result of very high hydrostatic pressure. Food Res. Int. 72:74-79.

Cadesky, L., M. Walkling-Ribeiro, K. T. Kriner, M. V. Karwe, and C. I. Moraru. 2017. Structural changes induced by high-pressure processing in micellar casein and milk protein concentrates. J. Dairy Sci. 100:7055-7070.

Campbell, W., M. A. Drake, and D. K. Larick. 2003. The impact of fortification with conjugated linoleic acid (CLA) on the quality of fluid milk. J. Dairy Sci. 86:43-51.

Chen, J., and J. R. Stokes. 2012. Rheology and tribology: Two distinctive regimes of food texture sensation. Trends Food Sci. Technol. 25:4-12.

Datta, N., A. J. Elliott, M. L. Perkins, and H. C. Deeth. 2002. Ultrahigh-temperature (UHT) treatment of milk: Comparison of direct and indirect modes of heating. Aust. J. Dairy Technol. 57:211-227.

de Wijk, R. A., and J. F. Prinz. 2005. The role of friction in perceived oral texture. Food Qual. Prefer. 16:121-129.

de Wijk, R. A., and J. F. Prinz. 2006. Mechanisms underlying the role of friction in oral texture. J. Texture Stud. 37:413-427.

des Gachons, C. P., E. Mura, C. Speziale, C. J. Favreau, G. F. Dubreuil, and P. A. Breslin. 2012. Opponency of astringent and fat sensations. Curr. Biol. 22:R829-R830.

Donato, L., and F. Guyomarc'h. 2009. Formation and properties of the whey protein/kappa-casein complexes in heated skim milk-A review. Dairy Sci. Technol. 89:3-29.

Engelen, L., and R. A. de Wijk. 2012. Oral processing and texture perception. Pages 159-176 in Food Oral Processing: Fundamentals of Eating and Sensory Perception. Wiley-Blackwell, Oxford, UK.

Gibbins, H., and G. Carpenter. 2013. Alternative mechanisms of astringency-What is the role of saliva? J. Text. Stud. 44:364-375.

Green, B. G. 1993. Oral astringency: A tactile component of flavor. Acta Psychol. (Amst.) 84:119-125.

Griffiths, M. W. 2010. Improving the Safety and Quality of Milk: Improving Quality in Milk Products. Elsevier, Amsterdam, the Netherlands.

Harwalkar, V. R., H. Cholette, R. C. McKellar, and D. B. Emmons. 1993. Relation between proteolysis and astringent off-flavor in milk. J. Dairy Sci. 76:2521-2527.

Havea, P., H. Singh, L. K. Creamer, and O. H. Campanella. 1998 Electrophoretic characterization of the protein products formed during heat treatment of whey protein concentrate solutions. J. Dairy Res. 65:79-91. 
Hayes, M. G., and A. L. Kelly. 2003. High pressure homogenisation of raw whole bovine milk (a) effects on fat globule size and other properties. J. Dairy Res. 70:297-305.

Jöbstl, E., J. O'Connell, J. P. A. Fairclough, and M. P. Williamson. 2004. Molecular model for astringency produced by polyphenol/ protein interactions. Biomacromolecules 5:942-949.

Josephson, R. V., E. L. Thomas, C. V. Morr, and S. T. Coulter. 1967. Relation of heat-induced changes in protein-salt constituents to astringency in milk systems. J. Dairy Sci. 50:1376-1383.

Jovanovic, S., M. Barac, O. Macej, T. Vucic, and C. Lacnjevac. 2007. SDS-PAGE analysis of soluble proteins in reconstituted milk exposed to different heat treatments. Sensors (Basel) 7:371-383.

Lee, A. P., D. M. Barbano, and M. A. Drake. 2017. The influence of ultra pasteurization by indirect heating versus direct steam injection on skim and $2 \%$ fat milks. J. Dairy Sci. 100:1688-1701.

Lenfant, F., C. Loret, N. Pineau, C. Hartmann, and N. Martin. 2009 Perception of oral food breakdown. The concept of sensory trajectory. Appetite 52:659-667.

López-Fandiño, R., J. Otte, and J. Van Camp. 2006. Physiological, chemical and technological aspects of milk-protein-derived peptides with antihypertensive and ACE-inhibitory activity. Int Dairy J. 16:1277-1293.

Lyster, R. 1964. The free and masked sulphydryl groups of heated milk and milk powder and a new method for their determination. J. Dairy Res. 31:41-51.

McCarthy, K. S., K. Lopetcharat, and M. A. Drake. 2017. Milkfat threshold determination and the effect of milkfat content on consumer preference of fluid milk. J. Dairy Sci. 100:1702-1711.

McMahon, D. J. 1996. Age-gelation of UHT milk: Changes that occur during storage, their effect on shelf life and the mechanism by which age-gelation occurs. In Proc. Heat treatments and alternative methods. IDF Symposium, Vienna (Austria), 6-8 Sep 1995. Int. Dairy Fed., Brussels, Belgium.

Meilgaard, M. C., G. V. Civille, and B. T. Carr. 2007. The Spectrum $^{\text {TM }}$ descriptive analysis method. Pages 189-253 in Sensory Evaluation Techniques. CRC Press, Boca Raton, FL.

Miller, J. L., and K. L. Watkin. 1996. The influence of bolus volume and viscosity on anterior lingual force during the oral stage of swallowing. Dysphagia 11:117-124.

Morales, F. J., C. Romero, and S. Jiménez-Pérez. 2000. Characterization of industrial processed milk by analysis of heat-induced changes. Int. J. Food Sci. Technol. 35:193-200.
Morris, E. R. 1983. Rheology of hydrocolloids. Pages 57-77 in Gums and Stabilisers for the Food Industry. Vol. 2. Pergamon Press, Oxford, UK

Ong, L., R. Dagastine, S. Kentish, and S. Gras. 2010. The effect of milk processing on the microstructure of the milk fat globule and rennet induced gel observed using confocal laser scanning microscopy. J. Food Sci. 75:E135-E145.

Pandey, P. K., H. S. Ramaswamy, and D. St-Gelais. 2000. Waterholding capacity and gel strength of rennet curd as affected by high-pressure treatment of milk. Food Res. Int. 33:655-663.

Phillips, L. G., M. L. Mcgiff, D. M. Barbano, and H. T. Lawless. 1995. The influence of fat on the sensory properties, viscosity, and color of lowfat milk. J. Dairy Sci. 78:1258-1266.

Rossetti, D., J. Bongaerts, E. Wantling, J. Stokes, and A. M. Williamson. 2009. Astringency of tea catechins: More than an oral lubrication tactile percept. Food Hydrocoll. 23:1984-1992.

Sherman, P. 1969. A texture profile of foodstuffs based upon welldefined rheological properties. J. Food Sci. 34:458-462.

Soukoulis, C., E. Lyroni, and C. Tzia. 2010. Sensory profiling and hedonic judgement of probiotic ice cream as a function of hydrocolloids, yogurt and milk fat content. Lebensm. Wiss. Technol. 43:1351-1358.

Stokes, J. R., M. W. Boehm, and S. K. Baier. 2013. Oral processing, texture and mouthfeel: From rheology to tribology and beyond. Curr. Opin. Colloid Int. 18:349-359.

Thiebaud, M., E. Dumay, L. Picart, J. Guiraud, and J. Cheftel. 2003. High-pressure homogenisation of raw bovine milk. Effects on fat globule size distribution and microbial inactivation. Int. Dairy J. 13:427-439.

Tran, H., N. Datta, M. Lewis, and H. Deeth. 2008. Predictions of some product parameters based on the processing conditions of ultrahigh-temperature milk plants. Int. Dairy J. 18:939-944.

Wehr, H. M., and J. F. Frank, ed. 2004. Standard Methods for the Examination of Dairy Products. 17th ed. Am. Publ. Health Assoc. Inc., Washington, DC.

Withers, C. A., M. T. Cook, L. Methven, M. A. Gosney, and V. V. Khutoryanskiy. 2013. Investigation of milk proteins binding to the oral mucosa. Food Funct. 4:1668-1674.

Withers, C. A., M. J. Lewis, M. A. Gosney, and L. Methven. 2014. Potential sources of mouth drying in beverages fortified with dairy proteins: A comparison of casein- and whey-rich ingredients. J. Dairy Sci. 97:1233-1247. 